\title{
KOLABORASI SMK MUTU, POSDAYA KOLBANDA DAN LPPM UNMER MALANG DALAM BERBAGI KETRAMPILAN
}

\author{
Agus Suprapto $^{1)}$, Mochammad Rofieq ${ }^{2)}$, Andi Poerwanto ${ }^{3)}$ \\ ${ }^{1,2)}$ Fakultas Teknik Universitas Merdeka Malang \\ 3) Fakultas Hukum Universitas Merdeka Malang \\ e-Mail : agussuprapto@yahoo.com
}

\begin{abstract}
Abstrak
SMK bertujuan untuk mempersiapkan lulusan yang dapat menerapkan keahlian dan ketrampilan di bidangnya, siap kerja dan mampu bersaing secara global. Untuk menjawab itu semua maka kegiatan proses belajar mengajar diarahkan pada penguatan hard skill,namun tidak mengesampingkan penguatan softskill nya. Untuk itu bebagai kerjasam telah dilakukan termasuk kerjsama dengan Unmer sebagai institusi yang peduli terhadap pengembangan pendidikan.

Dalam kerjasama ini antara kedua institusi saling bertukar ketrampilan yang dimiliki, dimana SMK Mutu memberikan pelatihan pembuatan krupuk kunyit kepada anggota posdaya binaan LPPM dan dosen Unmer Malang, sementara LPPM memberikan wawasan kewirausahaan dan posdaya binaan LPPM memberikan pelatihan pembuatan kerajinan berbahan barang bekas

Manfaat kegiatan pelatihan para anggota posdaya dan dosen bisa memanfaatkan lahannya untuk menanam kunyit dan daunnya bisa dimanfaatkan menjadi krupuk, sementara siswa smk mendapatkan pelatihan ketrampilan menggunakan barang bekas untuk menghasilkan berbagai hasil ketrampilan yang bernilai jual. Selain itu pelatihan ketrampilan berbahan barang bekas ini memiliki efek domino lingkungan sekitar menjadi lingkungan yang bersih karena sampah bisa dimanfaatkan dan dirubah menjadi barang baru dengan nilai jual.
\end{abstract}

Kata kunci : Ketrampilan, Krupuk Daun Kunyit, Kerajinan Berbahan Barang Bekas

\section{PENDAHULUAN}

SMK Muhammadiyah 7 Gondanglegi Malang (SMK MUTU) berdiri pada tahun 1994 atas prakarsa tokoh dan pimpinan cabang Muhammadiyah Gondanglegi Malang. Penandatanganan SK Pendiirian oleh Menteri Pendidikan Nasional RI, No 23428/MPK, tanggal 24-07-1994 dengan NSS : 324051815015

Pada awalnya SMK MUTU mengelola 2 Kompetensi keahlian: Teknik Kendaraan Ringan dan Teknik Instalasi Tenaga Listrik. Pada tahun 2008 membuka dua kompetensi keahlian : Perbankan dan Teknik Komputer \& Jaringan. Satu tahun kemudian 2019 menambah 1 kompetensi keahlian : Teknik Sepeda Motor. Tahun 2012 membuka kompetensi keahlian Farmasi. Dan tahun 2013 mengembangkan kompetensi Keperawatan, Perhotelan, Ototronik, dan Administrasi Perkantoran

SMK Mutu Menempati Areal tanah $20.000 \mathrm{~m} 2$ dari target ideal lahan $40.000 \mathrm{~m} 2$. Diantaranya $10.000 \mathrm{~m} 2$ di kampus 1, JL KH. Achmad Dahlan dan 10.000 m2 di Kampus 2 di jalan Singajayan Gondanglegi yang saat ini sedang di bangun gedung The Titanium Building 7 Lantai. Kampus 1 digunakan untuk ruang praktek siswa (RPS) dan Workshop dan kampus 2 digunakan untuk pusat layanan siswa, perkantoran, ruang teori, digital library, ruang IT, Auditorium dan public area

Sebagai institusi pendidikan SMK Mutu memiliki Visi dan Misi sebagai berikut:

Visi : Mewujudkan Sumber Daya Manusia yang Berakhlak Mulia yang Mampu Bersaing Secara Global

Misi :

1. Menciptakan suasana yang kondusif untuk mengembangkan potensi siswa melalui penekanan pada penguasaan kompetensi bidang ilmu pengetahuan dan teknologi serta Bahasa Inggris.

2. Meningkatkan penguasaan Bahasa Inggris sebagai alat komunikasi dan alat untuk mempelajari pengetahuan yang lebih luas.

3. Meningkatkan frekuensi dan kualitas kegiatan siswa yang lebih menekankan pada pengembangan ilmu pengetahuan dan teknologi serta keimanan dan ketakwaan yang menunjang proses belajar mengajar dan menumbuhkembangkan disiplin pribadi siswa.

4. Menumbuhkembangkan nilai-nilai ketuhanan dan nilai-nilai kehidupan yang bersifat universal dan mengintegrasikannya dalam kehidupan 
5. Menerapkan manajemen partisipatif dengan melibatkan seluruh warga sekolah, Lembaga Swadaya Masyarakat, stake holders dan instansi serta institusi pendukung pendidikan lainnya.

Sebagai perwujudan visi dan misinya SMK Mutu senantiasa membuka tangan untuk membangun jejaring. Untuk mengembangkan jejaring salah satu kegiatan yang dilakukan adalah kerjasama pengabdian kepada masyarakat bekerjasama dengan LPPM Unmer Malang dan Posdaya Kolbanda binaan LPPM Unmer Malang dalam hal penyuluhan kewirausahaan, pelatihan pembuatan krupuk daun kunyit dan pembuatan aneka kerajinan berbahan barang bekas. Harapannya dengan adanya kegiatan sharing ilmu pengetahuan siswa SMK Mutu dan anggota posdaya serta dosen Unmer Malang mendapatkan tambahan pengetahuan tentang pembuatan aneka produk yang berasal dari barang bekas maupun dari tanaman yang selama ini tidak termanfaatkan dengan baik (daun kunyit)

\section{METODE KEGIATAN}

Kegiatan pengabdian kepada masyarakat yang dilaksanakan oleh SMK Mutu dan LPPM Unmer Malang yang melibatkan siswa SMK, anggota posdaya dan dosen Unmer Malang ini dilakukan dengan beberapa kegiatan sebagai berikut:

1. Penyuluhan tentang kewirausahaan yang diberikan oleh tim LPPM Unmer Malang

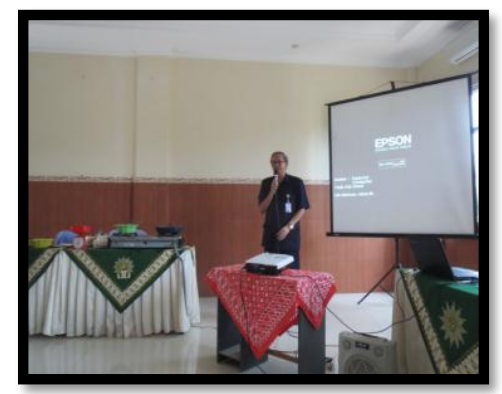

Gambar 1

Tim LPPM sedang menyampaikan materi kewirausahaan

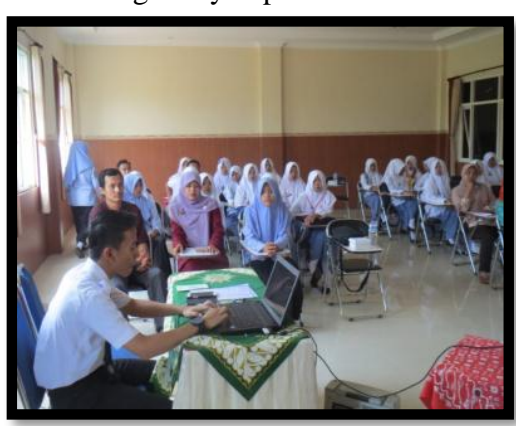

Gambar 2

Suasana dialog interaktif antara peserta dengan pemateri kewirausahaan
Dalam kegiatan ini disampaikan mindset orang selama ini lebih berorientasi kerja daripada berwirausaha. Dengan keterbatasan kesempatan kerja yang ada saat ini sudah saatnya merubah mindset orang untuk menjadi wirausaha agar bisa membuka lapangan kerja bagi dirinya sendiri dan masyarakat dilingkungannya. Pada kesempatan ini juga diberikan wawasan tentang alasan orang tidak mau berwirausaha, dengan memberikan contoh beberapa pengusaha yang bisa berhasil meskipun memiliki kekurangan misalnya tidak punya modal di contohkan Bob Sadino Memulai usaha dengan berjualan telor ke rumah-rumah tetangga, akhirnya menjadi milyuner Agrobisnis. Terlalu muda Mark Zuckerberg Di umur yang masih remaja sudah menjadi Milyuner berkat ciptaanya situs Facebook . Terlalu tua Colonel Sanders Memulai usahanya setelah berumur 60 tahun, setelah pensiun dari Angkatan Laut Amerika . Tidak punya pendidikan I Gusti Ngurah Anom berasal dari petani miskin, Hanya lulus SMP, Sekarang menjadi pengusaha konveksi terbesar di Bali, dimulai dari tukang cuci mobil

Sebagian materi yang diberikan dalam penyuluhan kewirausahaan sebagai berikut:

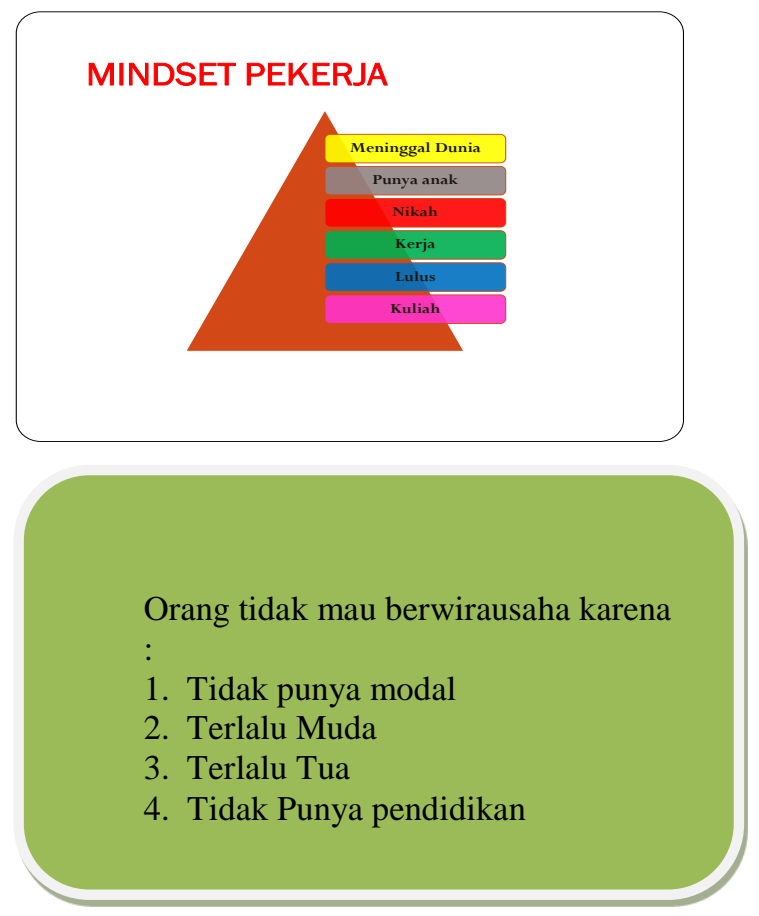

2. Pelatihan Pembuatan Krupuk Daun Kunyit

Daun kunyit yang selama ini terabaikan, ditangan dingin siswa SMK Mutu menjadi sangat besar artinya. Dengan menggunakan sari daun kunyit akan dapat dibuta kerupuk dengan citarasa yang sangat istimewa. 


\section{Bahan-bahan}

1. 150 gram Kanji

2. 200 gram daun kunyit diambil sarinya (blender dengan air $100 \mathrm{ml}$ )

3. 100 gram Bawang Merah parut

4. 100 gram Bawang Putih parut

5. 1 btr Telor

6. 100 gram Terigu protein sedang

7. $1 / 2$ sdt garam halus

8. Penyedap secukupnya

\section{Adonan Dasar Krupuk:}

9. 500 gram Terigu Protein Sedang

10. 250 gram Kanji

11. $1 / 2$ sdt garam halus

12. $100 \mathrm{ml} \mathrm{Air}$

\section{Langkah}

1. Campur kanji, tepung, sari daun kunyit,bawang merah+putih+telor+ garam dalam mangkok blender hingga halus seperti bubur

2. Campur adonan $1 \mathrm{yg}$ halus dengan bahan dasar Krupuk semua tepung trigu dan kanji aduk rata. Kalau kurang encer bisa ditambahkan air secukupnya

3. Kukus bahan sampai matang ( 15 menit),

4. jemur hingga mengering

5. Siap digoreng

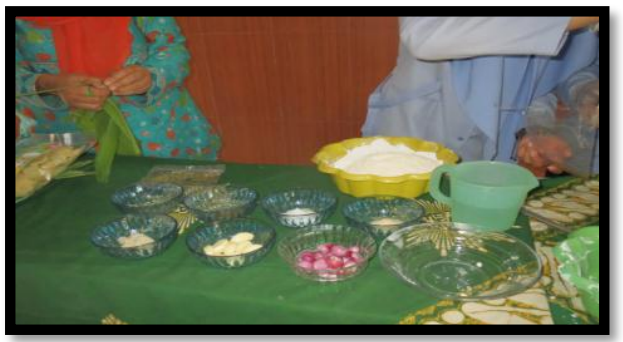

Gambar 3.

Bahan pembuatan krupuk kunyit

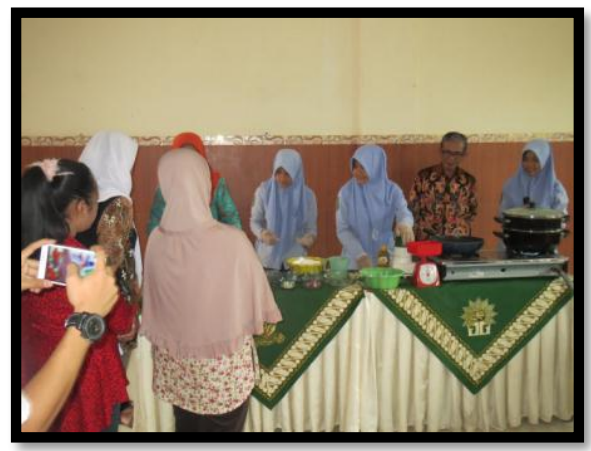

Gambar 4.

Persiapan pelaksanaan pembuatan kerupuk kunyit

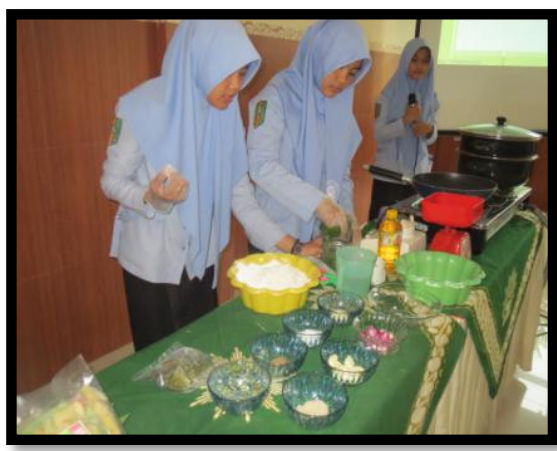

Gambar 5.

Mempersiapkan bahan bumbu

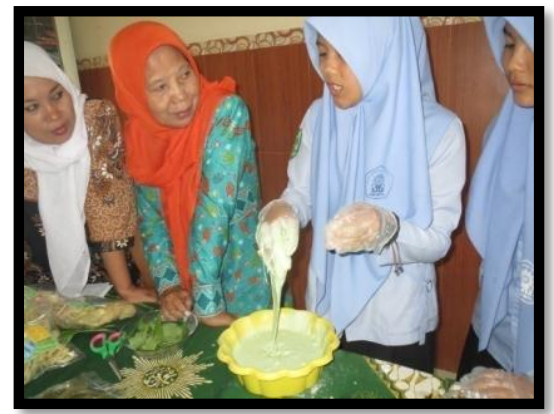

Gambar 6.

Proses pencampuran bahan satu dengan bahan dasar

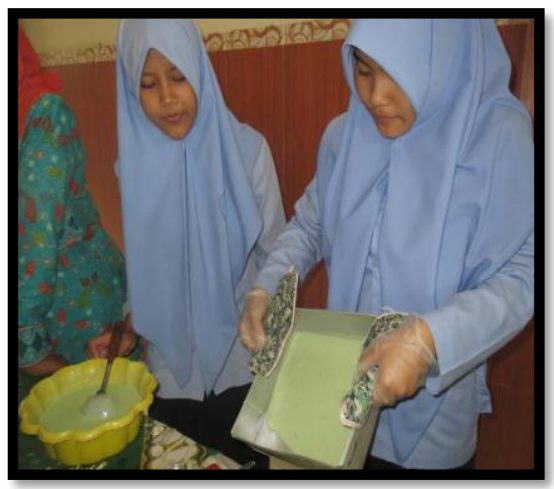

Gambar 7.

Masukkan adonan yang sudah tercampu kedalam loyang

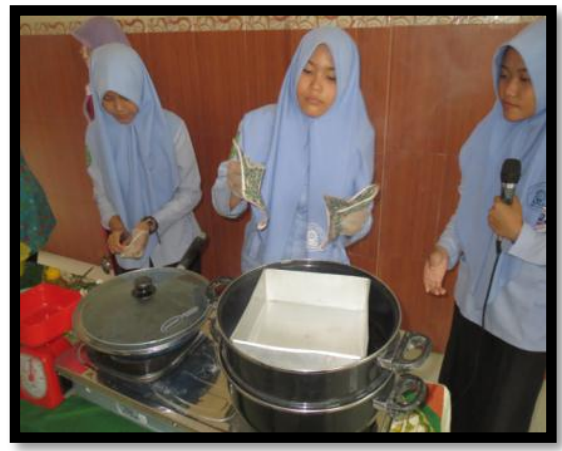

Gambar 8.

Proses Pengukusan 


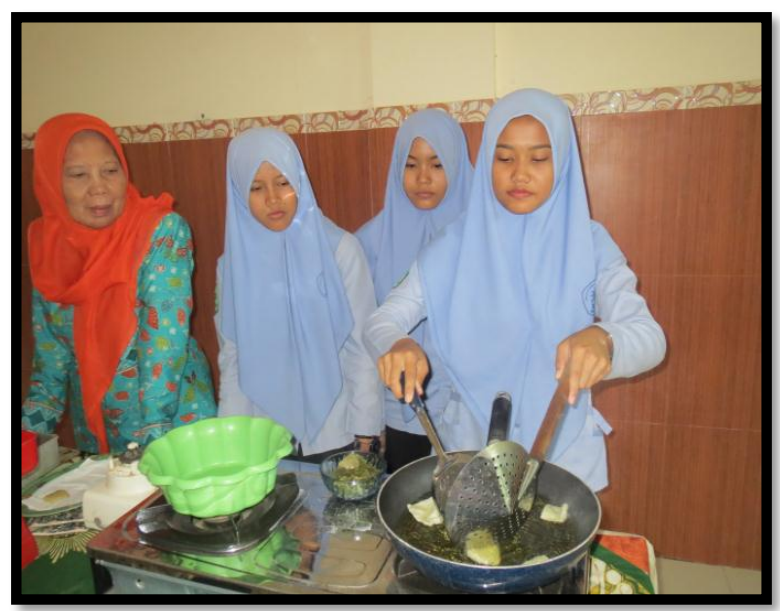

Gambar 9. proses penggorengan

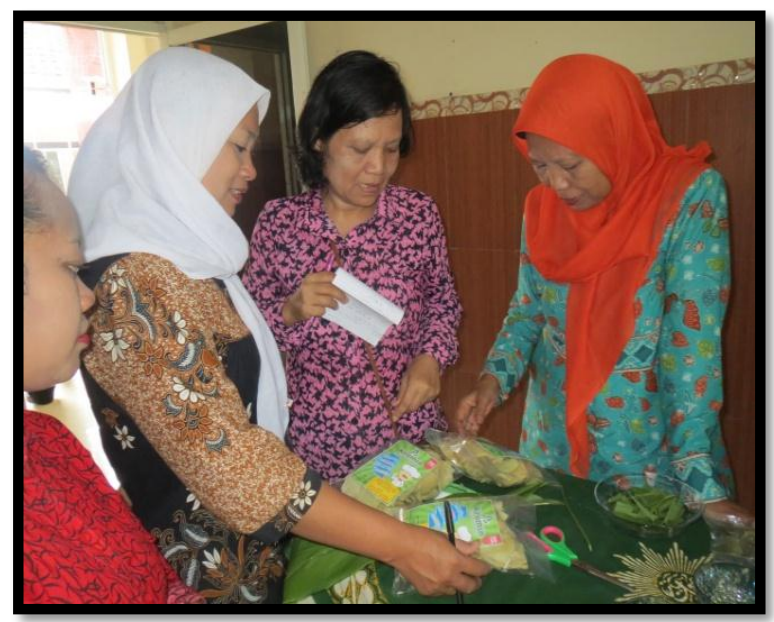

Gambar 10.

Krupuk daun kunyit yang sudah dikemas

3. Pelatihan pembuatan aneka kerajinan berbahan barang bekas.

Barang bekas bisa menjadi musibah bisa menjadi berkah. Barang bekas akan menjadi berkah jika kita bisa mengelola dengan baik. Selain bisa memberikan berkah rupiah barang bekas jika dikelola dengan baik akan mempengaruhi kebersihan lingkungan sekitar kita

Tim Posdaya Kulbanda adalah salah satu penggiat bank sampah malang dimana kegiatan beliau adalah memberikan penyuluhan tentang apa bagaimana sampah serta memberikan berbagai pelatihan pembuatan produk berbahan barang bekas. Pada kesempatan ini diberikan pelatihan pembuatan vas dan tempat pensil dari bahan koran bekas, piring plastik dari bahan gelas plastik serta bunga dari bahan gelas minuman plastik

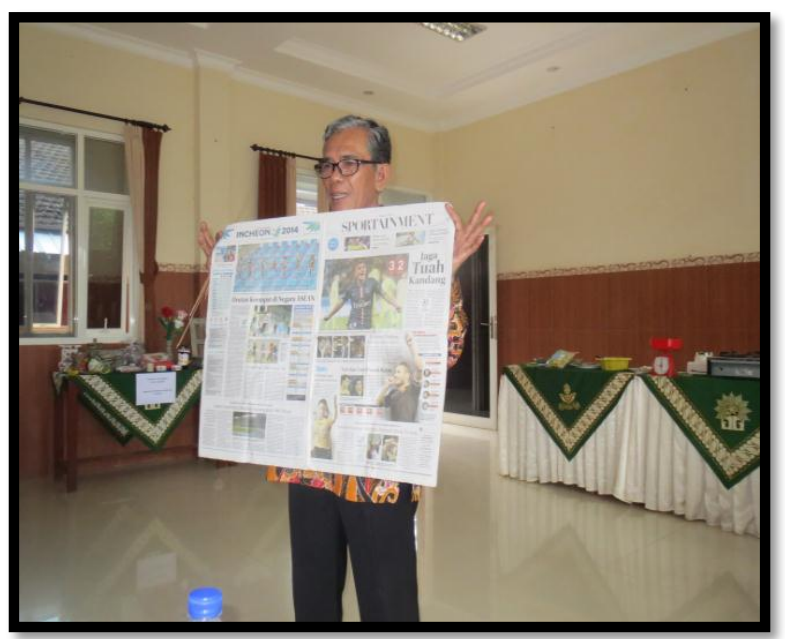

Gambar 11

Narasumber sedang menjelaskn apa manfaat kertas koran bekas

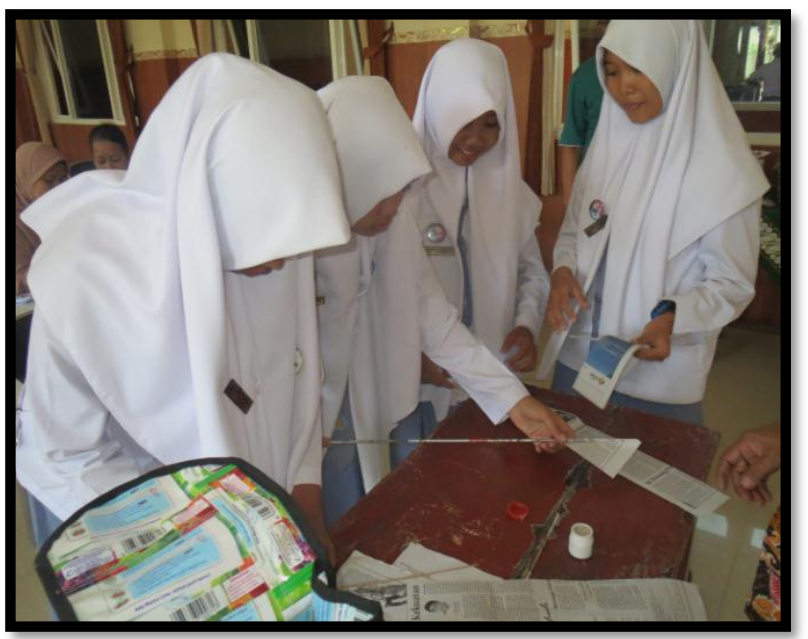

Gambar 12.

Siswa sedang mempraktekkan pembuatan vas dan tempat pensil dari kertas koran bekas

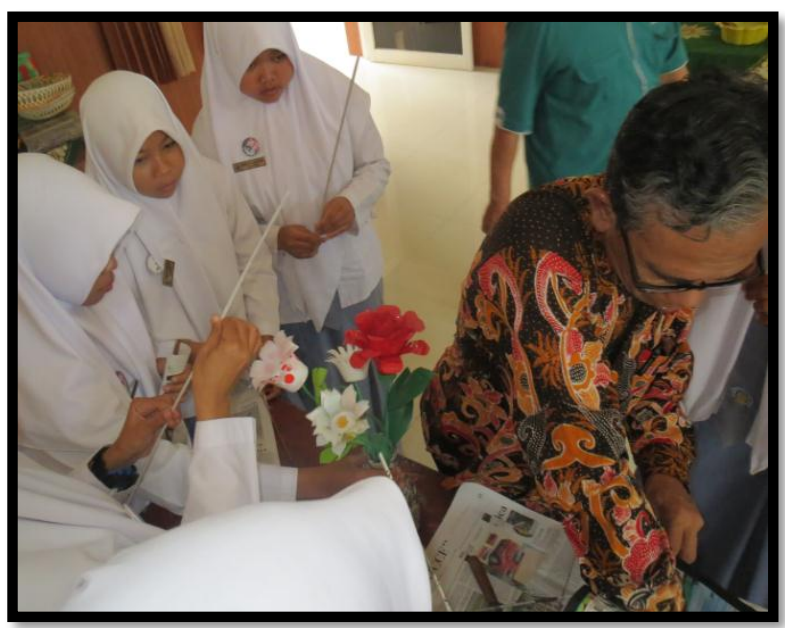

Gambar 13. Hasil kerajinan bunga berbahan dasar botol dan gelas plastik 


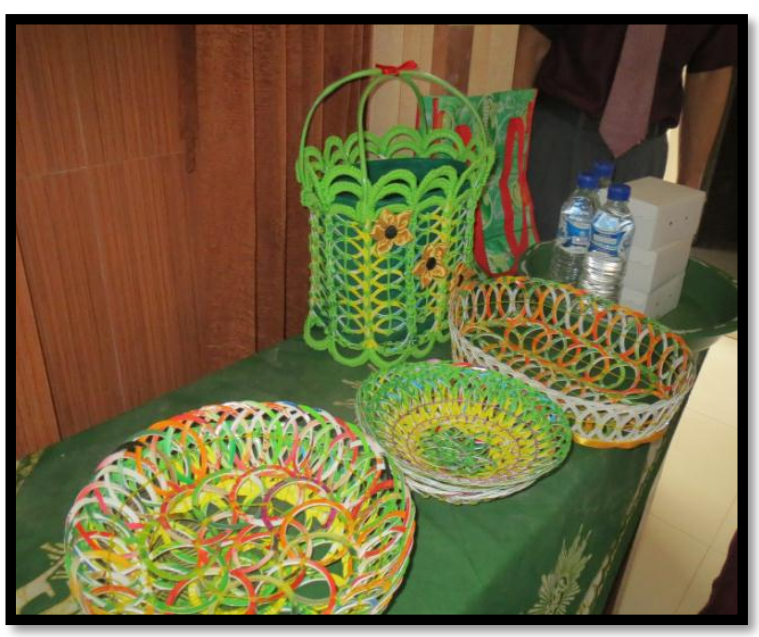

Gambar 14.

piring dan tas dari gelas minuman plastik

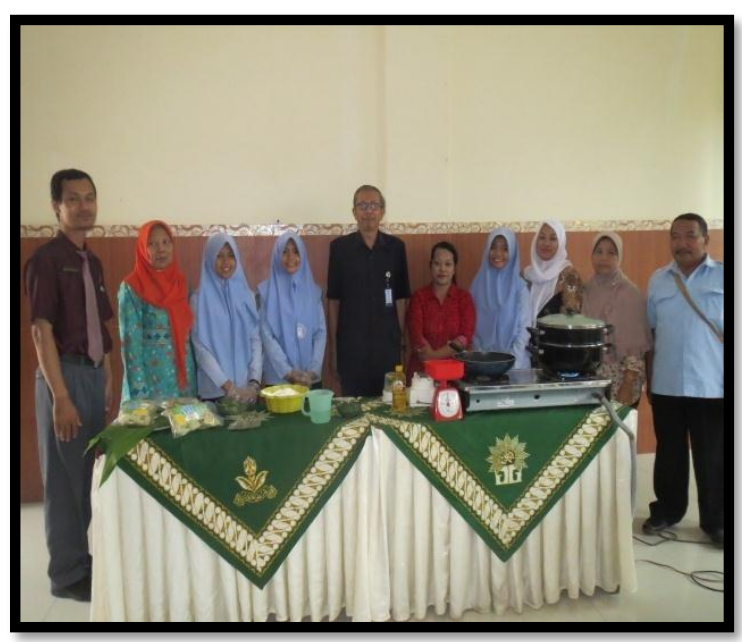

Gambar 15.

Narasumber dan sebagian peserta pelatihan

\section{HASIL DAN PEMBAHASAN}

Dari pelatihan yang dilakukan dengan saling memberikan informasi dan berbagi pengalaman sangat besar kemanfaatan yang bisa dihasilkan. Siswa SMK tergugah untuk senantiasa melakukan inovasi dan berkeinginan mandiri untuk berwirausaha tanpa harus menggantungkan diri bekerja pada orang lain. Dengan semangat yang menggebu dari para siswa SMK tersebut menggugah hati para dosen untuk dengan sukarela berbagi pengetahuan dan ketrampilan untuk membekali para siswa dengan ketrampilan sehingga kelak jika mereka lulus akan bisa mandiri tidak tergantung pada pihak luar, demikian juga dengan anggota posdaya adanya pelatihan ini menyemangati mereka untuk senantiasa mencoba membuat sesuatu dengan memanfaatkan segala potensi yang ada disekitarnya, sehingga apa yag dihasilkan bisa menopang ekonomi keluarga.

\section{KESIMPULAN}

\section{a. Kesimpulan}

Membangun jejaring merupakan langkah awal menuju sukses, karena dengan jejaring kita akan mendapatkan tambahan ilmu dan ketrampilan yang sangat berarti untuk kehidupan kita dimasa sekarang dan yang akan datang

\section{b. Saran}

Bagi semua pihak jika kita memiliki sesuatu yang lebih apakah itu pengetahuan atau ketrampilan akan lebih bermanfaat jika kemampuan dan ketrampilan yang kita miliki bisa kita bagi terhadap sesama

\section{REFERENSI}

Wiyani Wahyu, Dari Balck Gold untuk Pendidikan Anak Usia DiniJurnal ABM Mengabdi LPPM STIE Malangkucecwara ISSN 2477-6432 Volume 2 Des 2015

https://cookpad.com/id/cari/kerupuk\%20tepung\%20 beras 